\title{
Avaliação de parâmetros laboratoriais e clínicos de pacientes portadores de leucemia mielóide crônica submetidos ao tratamento com mesilato de imatinibe e sua relação com alterações observadas no estroma da medula óssea
}

\author{
Correlation between laboratory and clinical parameters of chronic myeloid leukemia patients \\ treated with imatinib mesylate and its relationship with stromal changes observed in
} bone marrow biopsy

Caroline R. de Jesus

Orientador: Cidônia de Lourdes Vituri

\section{Resumo}

A leucemia mielóide crônica (LMC) é caracterizada em 95\% dos casos pela presença do cromossomo Philadelphia $(\mathrm{Ph})$, que é resultante da translocação recíproca e equilibrada entre os braços longos dos cromossomos 9 e 22 . A conseqüência molecular desta translocação é a geração de uma proteína híbrida BCR-ABL, com atividade tirosina-quinase aumentada. O mesilato de imatinib é um potente competidor seletivo inibidor da proteína BCR-ABL. O estudo foi realizado em 22 pacientes portadores de LMC, cadastrados no Centro de Pesquisas Oncológicas de Santa Catarina (Cepon/SC) e tratados com mesilato de imatinibe, os quais foram acompanhados durante dois anos de tratamento. Os objetivos foram: verificar as sobrevidas global e livre de progressão, a resposta hematológica e citogenética, e verificar se existe correlação entre fibrose e vascularização da medula óssea com a resposta citogenética. A sobrevida dos pacientes incluídos no estudo foi de $95,46 \%$. A resposta hematológica completa foi alcançada em tempo médio de 1,5 meses, sendo que $72,73 \%$ mantiveram esta resposta durante os dois anos de acompanhamento. A sobrevida livre de progressão da doença foi observada em $86,36 \%$ dos pacientes. O tempo médio para obtenção da resposta citogenética foi de 8,78 meses e foi alcançada por $63,64 \%$ dos pacientes. A fibrose foi avaliada por meio da coloração de Gomori, demonstrando que a maioria dos pacientes $(59,09 \%)$ apresentou um grau de fibrose elevado na primeira biópsia; após o tratamento, grande parte $(72,73 \%)$ teve suas amostras normais. A vascularização foi avaliada pela marcação imunohistoquímica com anticorpo anti-CD34, sendo que 54,55\% dos pacientes apresentaram alteração importante na primeira biópsia de medula. Após o tratamento, 72,73\% das amostras apresentaram uma diminuição na contagem de vasos.
A resposta citogenética apresentou um alto grau de correlação tanto com a fibrose como com a vascularização $(p<0.05)$, demonstrando que, quanto maior o grau de fibrose, e maior número de vasos, menor a possibilidade da resposta citogenética ser alcançada. Este estudo vem fortalecer a hipótese de que o estroma da medula óssea de pacientes portadores de LMC apresenta alterações significativas, a ponto de interferirem na resposta terapêutica e terem relação direta com a sobrevida dos indivíduos.

Palavras-chave: Leucemia mielóide crônica; mesilato de imatinibe; resposta citogenética; medula óssea; fibrose; vascularização.

\section{Abstract}

Chronic myeloid leukemia (MLC) is characterized by the presence of the Philadelphia chromosome, the result of a reciprocal and balanced translocation between chromosomes 9 and 22, which is present in approximately $95 \%$ of all cases. The molecular consequence of this translocation is the generation of a hybrid protein called BCR-ABL, which presents increased tyrosine kinase activity. Imatinib mesylate is a powerful competitive and selective inhibitor of this protein. This study was performed with $22 \mathrm{MLC}$ patients, registered in Centro de Pesquisas Oncológicas de Santa Catarina (CEPON) who were treated with imatinib mesylate and followed-up over 2 years of treatment. The goals of this study were: to evaluate the overall and progression-free survival and the hematologic and cytogenetic responses and to verify whether there is any correlation between marrow stroma and the cytogenetic response. The survival rate of patients was $95.46 \%$. A complete

Tese de mestrado defendida em Programa de Pós-Graduação em Farmácia da Universidade Federal de Santa Catarina.

Correspondência: Cidônia de Lourdes Vituri

Universidade Federal de Santa Catarina

Centro de Ciências da Saúde, Departamento de Análises Clínicas - Campus Universitário - Trindade

88040-970 - Florianópolis-SC - Brasil

Fone:55 483318712 ou Fax:55 483319542

E-mail:cids@ccs.ufsc.br 
hematologic response was achieved in a mean time of 1.5 months, with $72.73 \%$ maintaining this response during the 2 years of monitoring. A progression-free survival rate was observed in $86.36 \%$ of patients during this period. The mean time to obtain a cytogenetic response was 8.78 months which was achieved in $63.64 \%$ of patients. Fibrosis was evaluated by Gomori staining (silver impregnation method). Most patients (59.09\%) presented a high degree of fibrosis in the first biopsy. After treatment, the fibrosis samples normalized for the majority of patients. Vascularization was assessed by immunohistochemistry marking using the CD34 antibody with $54.55 \%$ of patients presenting with significant changes in the first bone marrow biopsy. After treatment, $72.73 \%$ of the samples demonstrated a reduction in the number of vessels. The cytogenetic response had a high correlation both with fibrosis and vascularization $(\mathrm{p}<0.05)$ showing that the greater the degree of fibrosis and the larger the number of vessels, the lower the probability of achieving a cytogenetic response is. This study supports the hypothesis that the bone marrow stroma of patients with CML presents with significant changes, thereby interfering in the therapeutic response and consequently the survival of individuals.

Key words: Chronic myeloid leukemia; imatinib mesylate; bone marrow; cytogenetic response; hematologic response; fibrosis; vascularization.

Suporte Financeiro: Edital Jovem Pesquisador Funcitec/CNPq $500 / 2003$

Avaliação: A Revista Brasileira de Hematologia e Hemoterapia publica os resumos e abstracts de teses da área apresentados em entidades que tenham programas de pós-graduação reconhecidos pelo $\mathrm{MEC} / \mathrm{Capes}$ e considera a obtenção do título suficiente para sua publicação na forma como se propõe a seção.

Recebido: 07/04/2008

Aceito: $11 / 04 / 2008$ 